\title{
ПРЕЛИМИНАРНИ РЕЗУЛТАТИ БИОАНТРОПОЛОШКЕ АНАЛИЗЕ ХУМАНОГ ОСТЕОЛОШКОГ МАТЕРИЈАЛА СА НЕКРОПОЛЕ КОРМАДИН У ЈАКОВУ
}

\author{
Ксенија Ђукић, Веда Николић \\ Лабораторија за антропологију, Медицински факултет у Београду \\ Марио Царић, Марио Новак \\ Лабораторија за еволуциону антропологију и биоархеологију, \\ Центар за примењену биоантропологију, \\ Институт за антропологију, Загреб \\ e-mail: ksenja.djukic@gmail.com $\mid$ Претходно саопштење \\ Примљено: 1. 5. 2021. УДК: 902.2:572.72/.781.08(497.11) \\ Прихваћено: 9. 6. 2021. 903.5(497.11) 904:726.8”652”(497.11)
}

\begin{abstract}
Апстракт: У овом раду биће представљани прелиминарни резултати биоантрополошке анализе сачуваних скелетних остатака са локалитета Кормадин код Jaкова. Археолошки локалитет Кормадин код Јакова налази се у Србији, надомак Београда. Прва ископавања овог локалитета спроведена су још давне 1902. године, док је локалитет последњи пут истраживан 2008. године. Приликом археолошких истраживања на овом локалитету констатовани су неолитски стратум са три хоризонта становања и некропола из периода 5-6. века. Биоантрополошком анализом обухваћено је укупно 14 лобања. Међу анализираним лобањама било је 10 одраслих индивидуа и четворо деце. Код одраслих индивидуа седам је било мушког, а три индивидуе женског пола. Cribra orbitalia је констатована код свих дечјих индивидуа, присуство остеома код три одрасле индивидуе, као и једна зарасла импресиона фрактура на лобањи одрасле индивидуе женског пола. Када говоримо о денталном статусу, кариозне лезије биле су присутне код четири одрасле индивидуе, линеарна хипоплазија глеђи присутна је код укупно три лобање, док је периапикални процес био забележен у једном случају. Чињеница да је код свих дечјих индивидуа констатована cribra orbitalia говори у прилог тумачењу да услови живота и исхрана деце која су живела у оквиру ове заједнице нису били задовољавајући. Поред тога, на лобањи једне женске особе присутна је фрактура настала као последица удариа неког тупог предмета. Такав тип повреда, посебно на глави, у биоархеологији се најчешће тумачи као последица неког облика међуљудског насиља. С друге стране, чињеница да је ова особа повреду преживела и живела након ње може указати да су чланови ове заједнице можда познавали неке облике лечења оваквих повреда.
\end{abstract}

Кључне речи: Кормадин, Јаково, cribra orbitalia, импресиона фрактура, остеом 


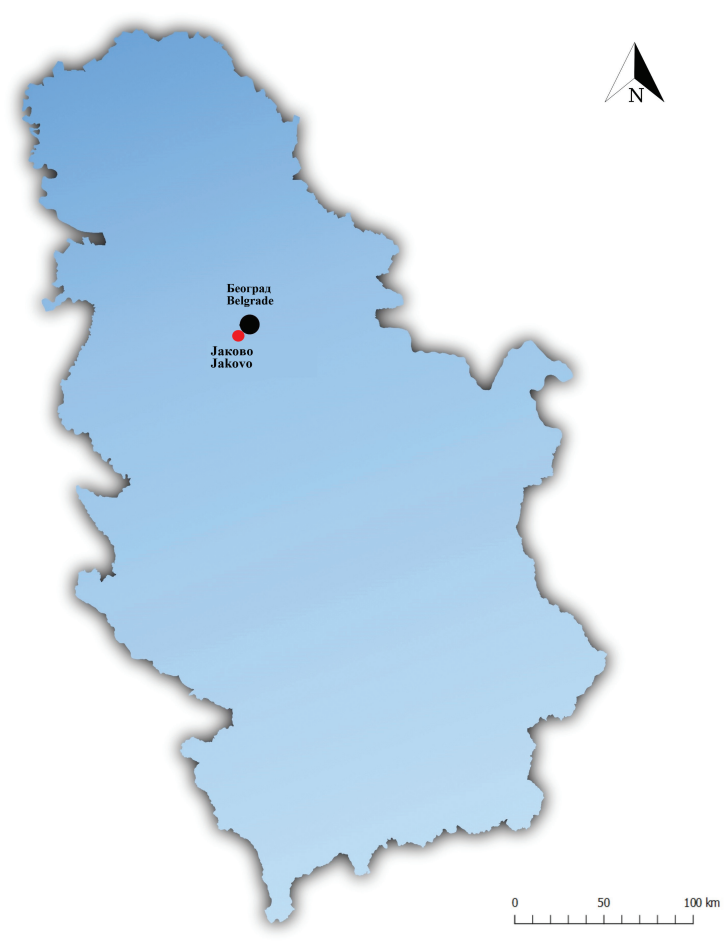

Мапа 1. Мапа Србије са Београдом

(Аутор: Skvoor/dreamstime.com. Модификовала К. Ђукић)

Map 1. Map of Serbia with Belgrade

(Author: Skvoor/dreamstime.com. Modified by K. Đukić)

\section{Увод}

Археолошки локалитет Кормадин код Јакова налази се у Србији, надомак Београда (Мапа 1), у оквиру општине Сурчин и катастарске општине Јаково (податак преузет из еКатастар непокретности: Подаци о непокретности). Сам локалитет је лоциран на месту где пут Сурчин-Бечмен скреће ка Јакову (Димитријевић, 1960). Недалеко од локалитета протиче поток Галовица, док је сам локалитет лоциран на таласастом узвишењу (сл. 1). Некада је ова локација у генералштабној карти била заведена као Јаковачки виногради или Курмадин (Димитријевић, 1960), док се данас, на основу података у Катастру непокретности обе парцеле на којима се локалитет налази, воде као приватна својина (податак преузет из еКатастар непокретности: Подаци о непокретности). Током претходних деценија локалитет Кормадин је био археолошки истраживан у више наврата. Прва ископавања овог локалите- 


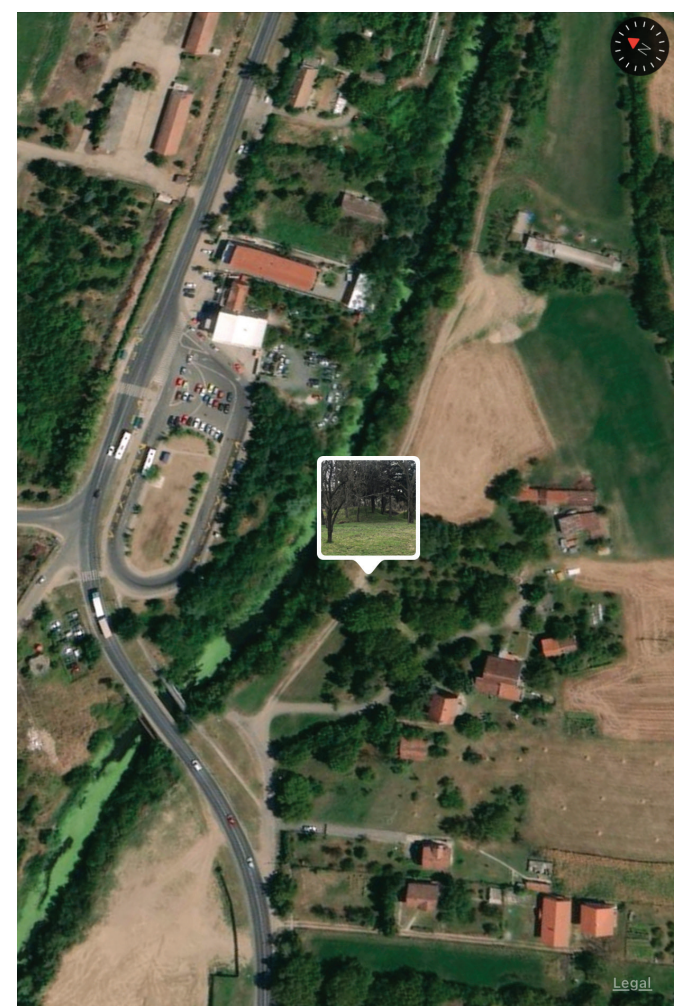

Сл. 1. Данашња позиција локалитета и изглед терена (преузето ca Google Earth. Модификовала К. Ђукић)

Fig. 1. Current position of the site and terrain configuration (from Google Earth. Modified by K. Đukić)

та почињу још давне 1902. године, када локални учитељ Анте Потуричић, иначе повереник Археолошког музеја у Загребу, отпочиње мања ископавања. Како наводи Даница Димитријевић (1960), на основу Потуричићевих описа поред богатог енеолитског насеља, на овом локалитету налази се и једна рецентнија некропола (Димитријевић, 1960). Потуричић спомиње да је пронађено три костура орјентисана у правцу исток-запад, са главом на западу, и да су уз њих констатовани гробни прилози у виду пређица, гвоздених ножева, маказа, ђинђува од ћилибара и стакла (Димитријевић, 1960). На основу ових гробних налаза он закључује да се ова три костура никако не могу определити у енеолитски период (Димитријевић, 1960). Заинтересован овим налазима, Јосип Бруншмид долази на локалитет и током 1904. и 1905. године наставља ископавања, којима сам руководи. У свом чланку објављеном 1960. године Д. Димитријевић детаљно наводи ток ископавања на овом 
локалитету, на основу кога можемо да закључимо да је од 1903. до 1905. године истражено најмање 45 гробова (Димитријевић, 1960). Целокупан археолошки и биоархеолошки материјал ископан на локалитету Кормадин код Јакова током 1903, 1904. и 1905. године данас се чува у Археолошком музеју у Загребу (Šeper, 1952)․․ У периоду од 1905. до 1955. године локалитет није археолошки истраживан, али је био у више наврата оштећен приликом копања војних ровова и експлоатације земље за оближњу циглану. Тако је уништен североисточни и источни део ове лесне заравни, а према сведочењу мештана Даница Димитријевић напомиње да је током ових радова пронађена велика количина праисторијске керамике, као и људских костију са прилозима (Димитријевић, 1960). С обзиром на околности у којима су ови налази пронађени, највећи део њих остаје неповратно изгубљен за науку. Међутим, на овом месту треба напоменути да су налази из укупно шест гробова доспели у Музеј Војводине у Новом Саду (Димитријевић, 1960). Ипак, чини се да су срећу да буду сачувани имали само гробни налази из истражених гробова, али не и скелетни остаци људи који су у њима били сахрањени ${ }^{2}$. Археолошка истраживања се на овој локацији настављају 1956. године и у континуитету трају до 1958. године (Димитријевић, 1960; Јовановић и Глишић, 1960). У том периоду истраживања се спроводе под покровитељством Народног музеја у Земуну, а руководилац археолошких истраживања била је Даница Димитријевић. Током ове три године истражена је површина од 450 $\mathrm{M}^{2}$, у оквиру које је ископано 26 такозваних скелетних гробова и две лобање (Димитријевић, 1960). Поред некрополе из 5-6. века (Димитријевић, 1960), констатован је праисторијски културни слој (Јовановић и Глишић, 1960). Покретни археолошки материјал, као и један мањи део остеолошког материјала откривених током ових систематских ископавања чува се у Музеју града Београда ${ }^{3}$. Током 2008. године спроведена су нова археолошка ископавања на овом локалитету. Констатовани су остаци стамбене архитектуре, која се датује у позну фазу винчанске културе, као и један гроб који се датује у период 5-6. века (Булатовић и др., 2010). Овим ископавањима руководио је Михаило

\footnotetext{
${ }^{1}$ Референца наведена у тексту односи се на археолошке налазе. Податак везан за чување биоантрополошког материјала добијен је захваљујући личној комуникацији аутора приложеног текста и колегинице из Археолошког музеја у Загребу. Овом приликом желимо да захвалимо кустоскињи Анити Дугоњић, која нам је уступила хумани остеолошки материјал.

2 Захваљујемо Станку Трифуновићу, музејском саветнику Музеја Војводине. Захваљујући његовом ангажовању дошли смо до сазнања да се у Музеју Војводине не налази биоантрополошки материјал са локалитета Кормадин у Јакову.

3 Захваљујемо Ники Стругар и Милошу Спасићу, кустосима у Музеју града Београда, који су нам за потребе биоантрополошке анализе уступили остеолошки материјал са локалитета Кормадин.
} 
Милинковић са Одељења за археологију Филозофског факултета у Београду, у сарадњи са Ником Стругар из Музеја града Београда и Александром Булатовићем из Археолошког института у Београду.

На основу свега наведеног можемо да закључимо да су до сада на локалитету Кормадин у Јакову приликом археолошких истраживања констатовани неолитски стратум са три хоризонта становања (Булатовић и др., 2010), као и некропола из периода 5-6. века (Димитријевић, 1960).

Иако је до данас овај локалитет у више наврата био предмет како интересовања тако и истраживања стручњака, и мада је до сада на њему укупно констатовано 56 гробова и две изоловано сахрањене лобање, хумани остеолошки материјал није био биоантрополошки анализиран нити су нам били познати било какви подаци о биолошкој прошлости људи који су на овој некрополи били сахрањени. Разлог оваквог стања истражености биоантрополошког материјала највероватније лежи у чињеници да су се истраживачи до пре две деценије углавном фокусирали на археолошки материјал, док је биоантрополошки материјал остајао у сенци свих истраживања, али и у томе да су за биоантрополошке анализе доступне само лобање са некрополе у Јакову. Истина, у литератури која се бави овим локалитетом, можемо да пронађемо податке како о старости у моменту смрти тако и о биолошком полу за готово сваки откривени скелет (Димитријевић, 1960). Ипак морамо да нагласимо да су ови подаци резултат претпоставке базиране на изгледу и употребним карактеристикама гробних налаза, а не на биолошким карактеристикама скелета, те се као такви морају узети са резервом.

Ако се све ово има у виду, предмет овог рада биће представљање прелиминарних резултата биоантрополошке анализе сачуваних скелетних остатака, тј. лобања са локалитета Кормадин код Јакова. У овом раду ће бити изостављен само скелет из гроба 1 , који је истражен током ископавања 2008. године. Овај скелет ће бити изостављен због тога што је једини у целости сачуван и као такав ће бити предмет засебне студије.

\section{Методолошки оквири}

У овом раду биће представљени прелиминарни резултати биоантрополошке анализе 14 лобања. Биоантрополошка анализа поменутих лобања обављена је у Лабораторији за еволуциону антропологију и биоархеологију Института за антропологију у Загребу, као и у Лабораторији за антропологију Медицинског факултета у Београду. На овом месту треба напоменути да је у Загребу обављена биоантрополошка анализа 11 лобања, док је у Београду обављена анализа укупно три лобање. Биоантрополошка анализа је 
Лобања сачувана у целости
Completely preserved skull $\quad \begin{aligned} & \text { Фрагментована лобања } \\ & \text { Fragmented skull }\end{aligned} \quad \begin{aligned} & \text { Парцијално сачувана лобања } \\ & \text { Partially preserved skull }\end{aligned}$

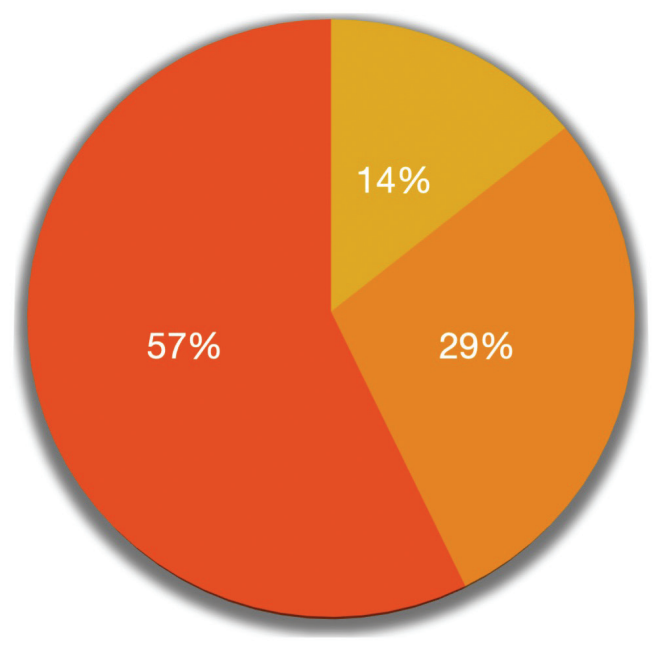

Сл. 2. Стање очуваности костију лобање

Fig. 2. State of preservation of the skull

подразумевала пре свега процену степена очуваности костију, процену биолошког пола, старости у моменту смрти, денталну анализу, као и анализу палеопатолошких лезија. Степен очуваности скелетног материјала процењиван је на основу три критеријума: стање очуваности костију лобање, степен очуваности костију лобање, као и степен очуваности кортикалне кости. Стање очуваности костију лобање односи се на фрагментованост костију лобање и у оквиру њега разликујемо: фрагментовану лобању, парцијално присутну лобању и лобању присутну готово у целости. Када говоримо о степену очуваности костију лобање, разликујемо три категорије: присутно мање од 50\% костију лобање, присутно од 50 до 70\% костију лобање и присутно више од 70\% костију лобање (Mikić, 1978). Степен очуваности кортикалне кости приказан је кроз три категорије: добро очуван кортекс (1), умерено очуван кортекс (2) и лоше очуван кортекс (3) (модификован систем који је предложила McKinley, 2004). Процена биолошког пола урађена је на основу морфолошких карактеристика лобање (Buisktra and Ubelaker, 1994), док је старост у моменту смрти, код одраслих особа, процењивана на основу денталног статуса (Buikstra and Ubelaker, 1994) и срастања лобањских шавова (Meindl and Lovejoy, 1985). Код скелетних остатака деце старост у моменту смрти процењивана је на основу раста и развоја круница и коренова примарних и сталних зуба (Ubelaker, 1984). Током денталне анализе пре 


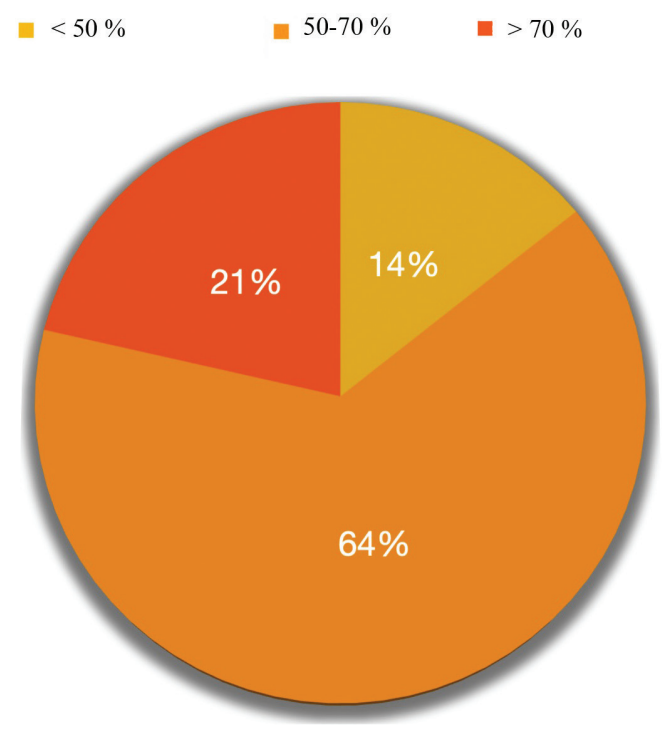

Сл. 3. Степен очуваности костију лобање

Fig. 3. Degree of preservation of the skull

свега смо бележили присутност и одсутност зуба. У случају одсутности зуба бележили смо да ли је он изгубљен пре или након смрти. Поред тога, током денталне анализе бележили смо присуство и степен кариозних лезија, степен истрошености зуба, присуство и степен изражености каменца те присуство и степен изражености ресорпције алвеоларног гребена (Brothwell, 1981; Smith, 1984). Анализа палеопатолошких лезија вршена је на основу препорука Буикстре (Buikstra, 2019). Када говоримо о физиолошком стресу, праћени су само они индикатори који остављају траг на костима лобање. Cribra orbitalia (CO) анализирана је у складу са препорукама Патрише Стјуарт-Макадам (Stuart-Macadam, 1985), а линеарна хипоплазија глеђи у складу са Ортнеровим препорукама (Ortner, 2003).

\section{Резултати}

Од укупно четрнаест анализираних лобања највећи број њих био је у релативно лошем стању очуваности. Лоше стање очуваности се пре свега огледа у томе што је највећи број лобања био присутан само парцијално, укупно њих осам (57\%), док је у случајевима где је била присутна готово цела лобања, она је најчешће била у фрагментованом стању (сл. 2 и 3). Сачуване у целости су лобање са ознакама 16 (ископавања 1904. година) и 14 (ископа- 
Добро очуван кортекс Well-preserved cortex
- Средње очуван кортекс Moderately preserved cortex
— Лоше очуван кортекс Low preserved cortex

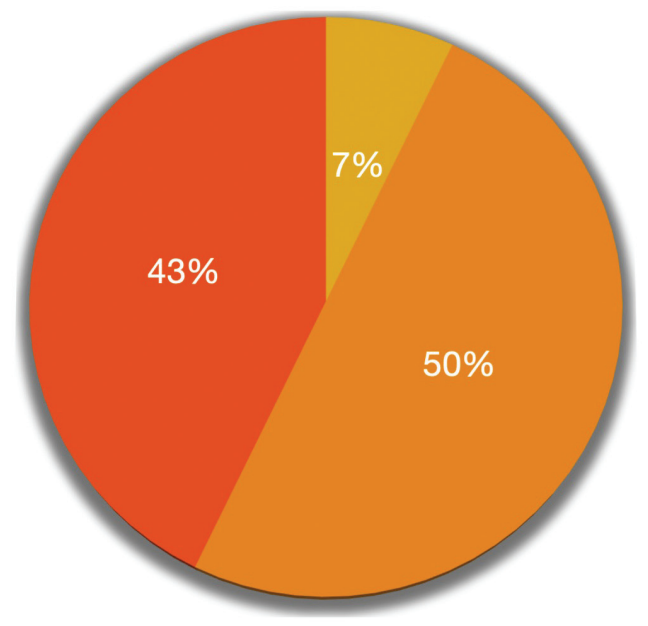

Сл. 4. Степен очуваности кортикалне кости

Fig. 4. Degree of preservation of the cortical bones

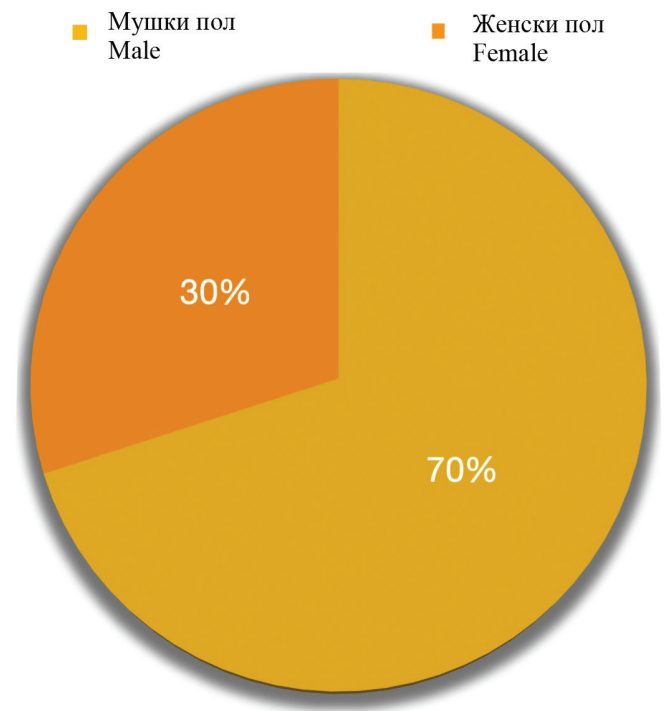

Сл. 5. Дистрибуција пола

Fig. 5. Sex distribution 


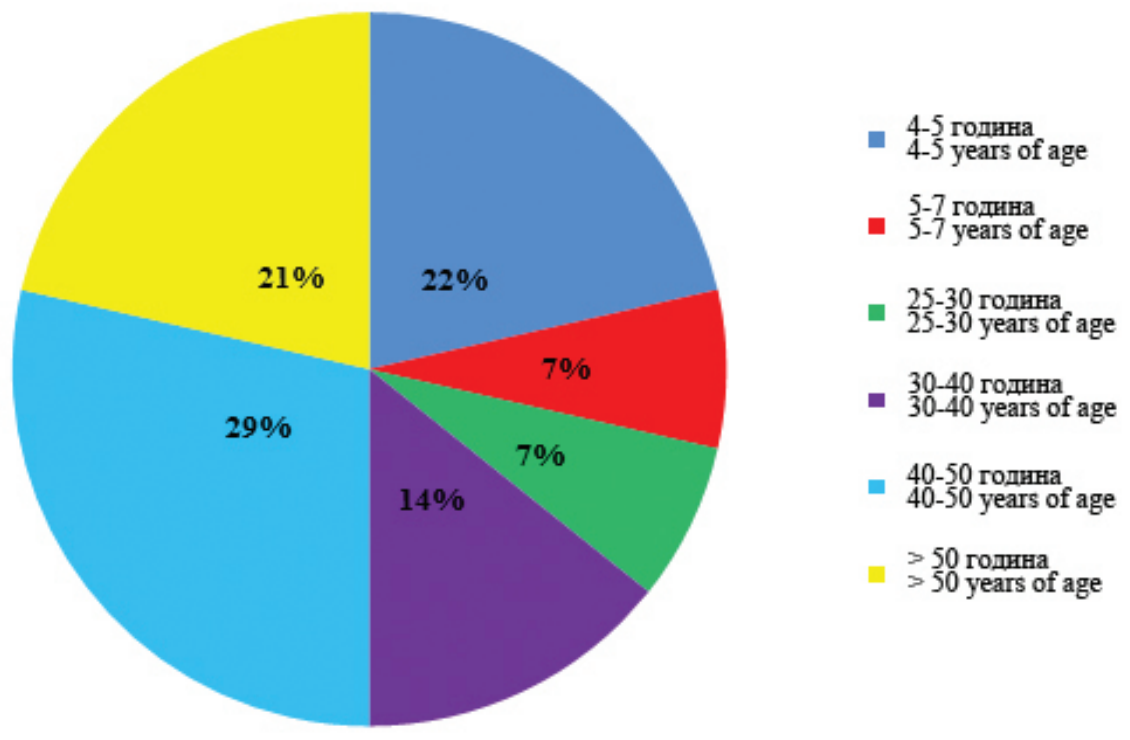

Сл. 6. Старосна дистрибуција

Fig. 6. Age distribution

вања 1958. година). Степен очуваности кортикалне кости углавном се креће од умерено очуваног (50\%) до лоше очуваног кортекса (сл. 4). Међу пронађеним лобањама укупно је било десет одраслих индивидуа и четворо деце. Код одраслих индивидуа, седам је било мушког пола, док су три индивидуе биле женског пола (сл. 5). Дечје индивидуе су биле старости од 4 до 5 година (три индивидуе) и 5 до 7 година у моменту смрти (једна индивидуа). Код пет одраслих индивидуа могли смо да прецизније одредимо старост, док је у осталим случајевима старост у моменту смрти одређена у ширем распону (сл. 6). Старосне категорије формиране су у складу са оним критеријумима које нам је диктирао степен очуваности скелетног материјала, те нису униформне и усклађене са неком до сада препорученом категоризацијом (табела 1).

Што се тиче анализе денталног статуса у 12 од 14 случајева биле су сачуване вилице, међу којима су у само шест случајева биле присутне и горња и доња вилица. У оваквим околностима присутности и сачуваности скелетног материјала веома је тешко анализирати дентални статус и омогућити увид у дентално здравље. Ако се то има у виду, резултати ће даље бити представљени описно и по индивидуама, и то само у случајевима у којима су патолошке промене биле уочене. Кариозне лезије биле су присутне код четири одрасле индивидуе, и то кариозна лезија у зачетку код једне особе, развијен каријес који не захвата више од половине површине крунице зуба 


\begin{tabular}{|c|c|c|c|}
\hline $\begin{array}{l}\text { Број гр оба/л обање } \\
\text { Number of grave/skull }\end{array}$ & $\begin{array}{l}\text { Пол } \\
\text { Sex }\end{array}$ & $\begin{array}{c}\text { Старост у моменту } \\
\text { смq тн } \\
\text { Age-at-death }\end{array}$ & $\begin{array}{l}\text { Место где се материјал } \\
\text { тренутно чува } \\
\text { Place where material is } \\
\text { currently stored }\end{array}$ \\
\hline 3 & $\begin{array}{l}\text { Женско } \\
\text { Female }\end{array}$ & $40-50$ & $\begin{array}{c}\text { Apx еолошки музеј у } \\
\text { 3ar peбy } \\
\text { The Archaeol ogical } \\
\text { Museum in Zagreb }\end{array}$ \\
\hline $9(21)$ & $\begin{array}{l}\text { Myшко } \\
\text { Male }\end{array}$ & $30-40$ & $\begin{array}{c}\text { Apx еолошки музеј у } \\
\text { Загребу } \\
\text { The Archaeological } \\
\text { Museum in Zagreb }\end{array}$ \\
\hline 14 & $\begin{array}{l}\text { Zere } \\
\text { Child }\end{array}$ & $4-5$ & $\begin{array}{l}\text { Mysej града Беорада } \\
\text { Belgrade City Museum }\end{array}$ \\
\hline $15 \mathrm{~A}$ & Child & $4-5$ & $\begin{array}{c}\text { Apx еолошки музеј у } \\
\text { Загребу } \\
\text { The Archaeol ogical } \\
\text { Museum in Zagreb }\end{array}$ \\
\hline 155 & $\begin{array}{l}\text { Myшко } \\
\text { Male }\end{array}$ & $>45$ & $\begin{array}{l}\text { Apx еолошки музеј у } \\
\text { Загребу } \\
\text { The Archaeol ogical } \\
\text { Museum in Zagreb }\end{array}$ \\
\hline $16(1904)$ & $\begin{array}{l}\text { Zere } \\
\text { Child }\end{array}$ & $4-5$ & $\begin{array}{c}\text { Apx еолошки музеј у } \\
\text { Загребу } \\
\text { The Archaeol ogical } \\
\text { Museum in Zagreb }\end{array}$ \\
\hline 16 & $\begin{array}{l}\text { Myшко } \\
\text { Male }\end{array}$ & $>40$ & $\begin{array}{c}\text { Myзеј града Беорада } \\
\text { Belgrade City Museum }\end{array}$ \\
\hline 17 & $\begin{array}{l}\text { Женско } \\
\text { Female }\end{array}$ & $>50$ & $\begin{array}{c}\text { Apx еолошки музеј у } \\
\text { Загребу } \\
\text { The Archaeol ogical } \\
\text { Museum in Zagreb }\end{array}$ \\
\hline 18 & $\begin{array}{l}\text { Myшко } \\
\text { Male }\end{array}$ & $>40$ & $\begin{array}{l}\text { Mysej града Беорада } \\
\text { Belgrade City Museum }\end{array}$ \\
\hline $21(14)$ & $\begin{array}{l}\text { Mушшко(?) } \\
\text { Male(?) }\end{array}$ & $28-36$ & $\begin{array}{l}\text { Apx еолошки музеј у } \\
\text { Загребу } \\
\text { The Archaeol ogical } \\
\text { Museum in Zagreb }\end{array}$ \\
\hline 22 & $\begin{array}{l}\text { Женско } \\
\text { Female }\end{array}$ & $>50$ & $\begin{array}{c}\text { Aрx еолошки музеј у } \\
\text { Загребу } \\
\text { The Archaeological } \\
\text { Museum in Zagreb }\end{array}$ \\
\hline 30 & $\begin{array}{l}\text { Zere } \\
\text { Child }\end{array}$ & $5-7$ & $\begin{array}{c}\text { Apx еолошки музеј у } \\
\text { Загребу } \\
\text { The Archaeological } \\
\text { Museum in Zagreb }\end{array}$ \\
\hline$?$ & $\begin{array}{l}\text { Myшко } \\
\text { Male }\end{array}$ & $30-40$ & $\begin{array}{c}\text { Apx еолошки музеј у } \\
\text { Загребу } \\
\text { The Archaeological } \\
\text { Museum in Zagreb }\end{array}$ \\
\hline
\end{tabular}

Табела 1. Полна и старосна структура анализираног материјала

Table 1. Sex and age distribution of the analysed material 

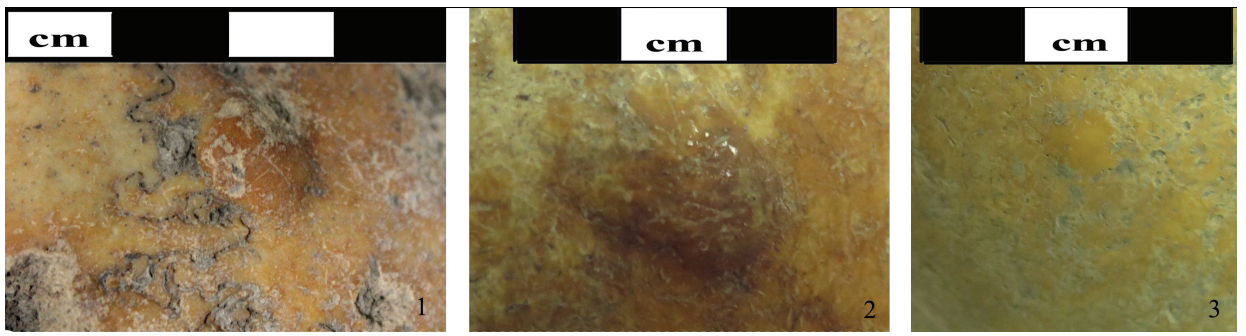

Сл. 7. Остеоми: 1) лобања са ознаком 16, 2) лобања са ознаком 21(14), 3) лобања са ознаком 22 (Фотографисао М. Царић, модификовала В. Николић)

Fig. 7. Osteoma: 1) skull number 16, 2) skull number 21(14), 3) skull number 22 (Photo by M. Carić, modified by V. Nikolić)

у два случаја, лезија које је захватила више од половине површине крунице код једног случаја и кариозна лезија која је поред крунице захватила и корен зуба код једног случаја. Код дечјих индивидуа нема знакова кариозних лезија. Линеарна хипоплазија глеђи присутна је код укупно три лобање. Периапикални процес присутан је у нивоу врха корена другог кутњака у горњој вилици са десне стране код лобање са ознаком 21(14).

Током биоантрополошке анализе cribra orbitalia констатована је код свих дечјих индивидуа, присуство остеома код три одрасле индивидуе, као и једна зарасла импресиона фрактура лобање одрасле индивидуе. На лобањи са ознаком 16, на десној паријеталној кости непосредно уз сагитални шав, а супериорно од ламбдоидног шава, приказује се дугметасто коштано испупчење, промера 1,1 цм, макроскопски компактне грађе, које најпре одговара остеому (сл. 7, 1) (Buikstra, 2019). На истој лобањи, латерално и антериорно од претходно описане промене, непосредно испод tuber-a parietale приказује се кружни дефект у кости који захвата обе табуле. Дефект је димензија 2,9 x 3,4 цм. Ова промена је порозних, делимично облих ивица, са видљивим порозним зонама у компактној грађи околне спољашње ламине. На ивицама и у непосредној околини описаног дефекта не уочавају се трагови употребе инструмената (сл. 8). Промена је највероватније настала као последица неког тафономског процеса, а с обзиром на то да се не уочавају трагови глодања или неке сличне интервенције, највероватније је да је настала као последица дејства корена неке биљке. На лобањи са ознаком 21(14), постеролатерално на паријеталној кости непосредно изнад темпоралног шава, а каудално од tuber-a parietale, приказује се коштана творевина овалног облика, димензија приближно 1,5 х 1 цм, макроскопски компактног изгледа, која диференцијално дијагностички најпре одговара остеому (сл. 7, 2) (Buikstra, 2019). На лобањи са ознаком 22, непосредно медијално од tuber-a parietale, 


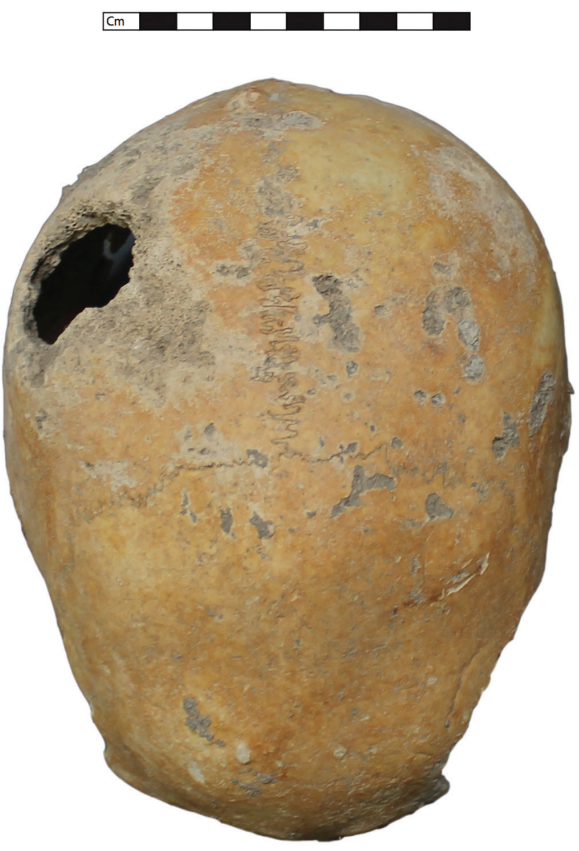

Сл. 8. Лобања са кружним дефектом (Фотографисала и модификовала В. Николић) Fig. 8. Skull with a circular defect (Photo and modification by V. Nikolić)

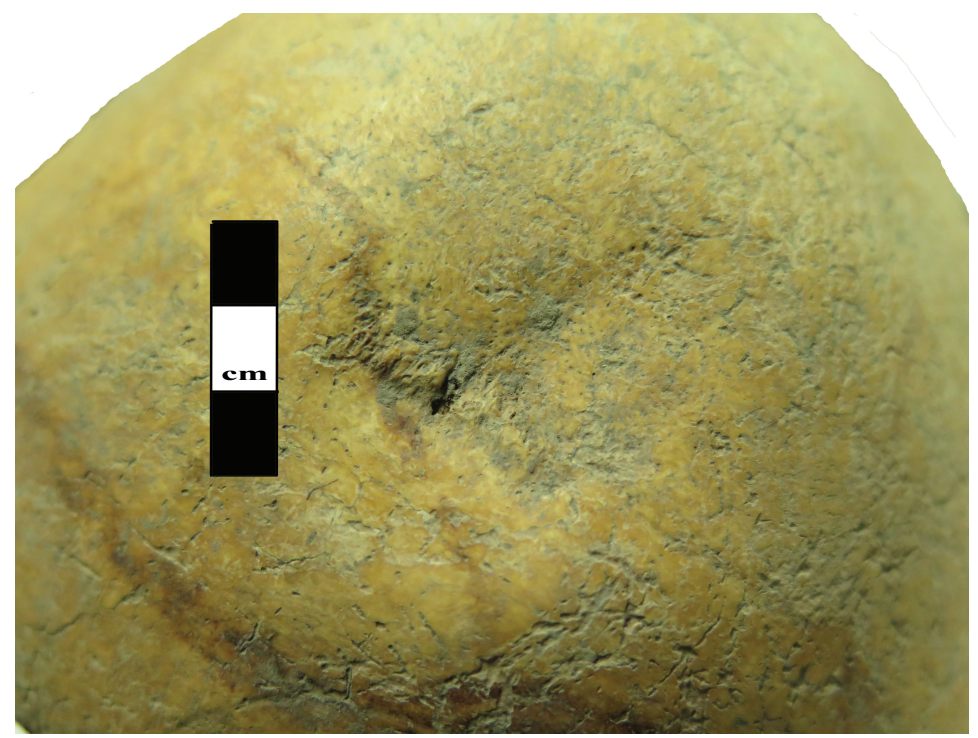

Сл. 9. Лобања са импресионом фрактуром

(Фотографисао М. Царић, модификовала В. Николић)

Fig. 9. Skull with an impression fracture (Photo by M. Carić, modified by V. Nikolić) 

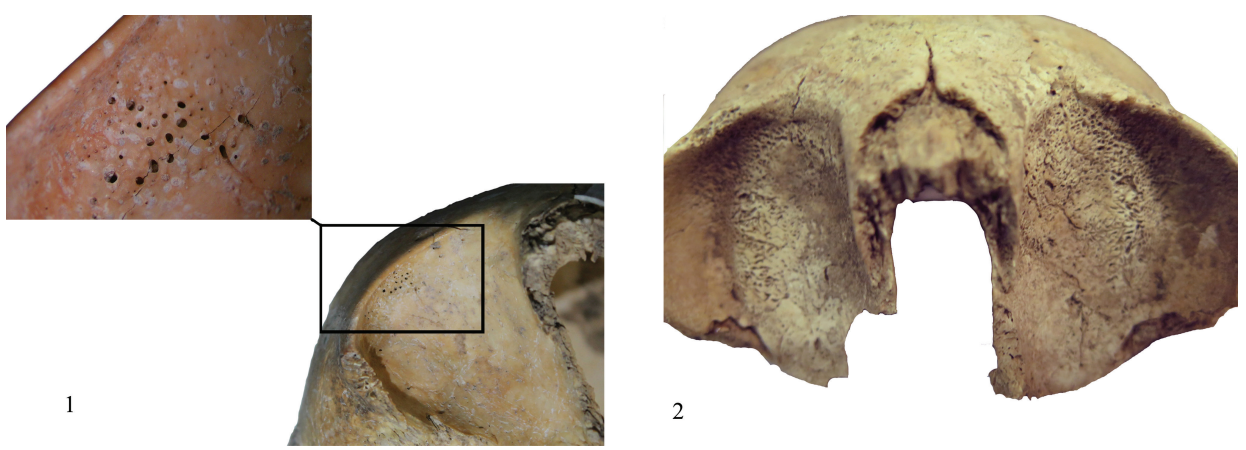

Сл. 10. Cribra orbitalia. 1) блага до умерена залечена cribra orbitalia (Фотографисала и модификовала В. Николић), б) активна cribra orbitalia (Фотографисао М. Царић, модификовала В. Николић)

Fig. 9. Cribra orbitalia. 1) light to medium healed cribra orbitalia (Photo and modification by V. Nikolić) 2) active cribra orbitalia (Photo by M. Carić, modified by V. Nikolić)

на десној паријеталној кости, приказује се коштана проминенција кружног облика, промера око 0,6 цм, која најпре одговара остеому (сл. 7, 3) (Buikstra, 2019). Непосредно каудомедијално од претходно описане промене на истој паријеталној кости присутна је неправилна троугласта депресија, димензија 1,6 х 1 цм, рељефастог и централно поротичног дна са знацима зарастања (сл. 9). У истом нивоу на унутрашњој табули приказује се конвекситет, који кореспондира облику описане промене. Диференцијално дијагностички налаз описане промене најпре одговара трауми са знацима комплетног зарастања на унутрашњој табули и некомплетног зарастања спољашње табуле (Buikstra, 2019). Поред остеома и трауме, на истој лобањи, на унутрашњој ламини фронталне кости уочавају се изражене арахноидне гранулације, које представљају налаз у склопу анатомских варијација (Gray et al., 2005).

Када говоримо о маркерима физиолошког стреса, cribra orbitalia je била присутна на укупно четири лобање, тј. код свих дечјих лобања које су обухваћене овом анализом. У случајевима лобања са ознакама 14, 16 (1904) и 30 на крововима орбита присутне су поротичне промене, које даље могу указати на постојање зарасле СО градуса 1-2 (сл. 10, 1). У случајевима лобања означеним 14 и 16 (1904) ради се о деци која су у моменту смрти била старости између 4 и 5 година, док је лобања 30 припадала детету које је у моменту смрти имало између 5 и 7 година. У два од три претходно наведена случаја поротичне промене су захватиле само једну орбиту, док се код једног случаја ради о билатералној СО. Изузетак чине скелетни остаци детета означени 15(А). Наиме, код овог детета сводови орбита су обострано у це- 
лости захваћени израженом рељефастом и порозном површином (сл. 10, 2). У овом случају ради се о такозваној активној форми СО.

Поред свега, један од најзначајнијих налаза са ове некрополе, а када говоримо о хуманом остеолошком материјалу, свакако је једна вештачки деформисана лобања. Ова лобања је припадала особи женског пола која jе у моменту смрти имала више од 50 година. Резултати биоантрополошке анализе, анализе стабилних изотопа, као и резултати анализе древне ДНК биће накнадно објављени. Лобања има ознаку 17 и чува се у Археолошком музеју у Загребу.

\section{Дискусија}

С обзиром на то да су нам за биоантрополошку анализу биле доступне само лобање, као и да смо прикупили 14 лобања из укупно археолошки истражених 56 гробова, било какво дискутовање о палеодемографским подацима морамо изоставити. Претходно приказани резултати који указују да је у анализираном остеолошком материјалу био заступљен већи број лобања мушког пола свакако се не може тумачити. Добијени резултати се заправо односе само на остеолошки материјал који је тренутно био доступан за анализу, а будући да нам критеријуми коришћени при одабиру лобања које ће бити сачуване нису познати, ни на који начин не можемо ове резултате користити за добијање коначне демографске слике некрополе у Јакову. Ипак, у даљем тексту биће продискутовано о резултатима анализа денталног статуса, као и налазима палеопатолошких промена.

Ако се осврнемо на резултате денталних анализа, будући да су описни и парцијални, морамо да нагласимо да би свака дискусија и њихово тумачење били непотпуни. Ипак, оно што можемо да закључимо јесте да код дечјих индивидуа није било трагова патолошких промена на зубима, док су код одраслих патолошке промене спорадичне и не представљају значајан сигнал који би нам омогућио употпуњавање слике о биолошкој прошлости популације која је своје мртве сахрањивала на некрополи у Јакову.

Најчешће присутне палеопатолошке промене код анализираних лобања свакако су остеоми. Остеоми су бенигни тумори кости које гради добро организована зрела кост. Њихова етиологија је још увек непозната, а њихово диспластично и неопластично порекло још увек није довољно истражено (Czerniak, 2016). По својој грађи могу се разврстати у три категорије. Првој припадају они остеоми које гради густа и зрела ламенарна кост, другој припадају спонгиозни остеоми, тј. они у чијој грађи доминира спонгиозно коштано ткиво, и у последњу категорију се убрајају они који 
су мешовите грађе (Baumhoer and Bras, 2013). Готово увек су локализовани на краниофацијалном скелету, међутим, могу се јавити и у дијафизама дугих костију (Buikstra, 2019). Када говоримо о клинички дијагностикованим остеомима, у великом броју случајева, до саме дијагнозе долази због тога што су се коштане промене прошириле у фронталне, параназалне синусе или орбиту, и на тај начин проузроковале појаву симптома (Greenspan and Borys, 2016). У археолошком материјалу дијагностиковање остеома локализованих у параназалним синусима и орбитама далеко је ређе од оних који се налазе на спољашњим ламинама кранијалних костију (Premužić et al., 2013). Остеоми који су локализовани на спољашњим ламинама кранијалних костију не проузрокују никакве симптоме и не захтевају никакав третман. Међутим, код оних остеома који су локализовани у фронталним или параназалним синусима или орбитама у изузетним случајевима може доћи до значајне нодуларне пројекције у предњу лобањску јаму која може изазвати компресију фронталног режња мозга (Buikstra, 2019). На лобањама са некрополе у Јакову, у сва три случаја, остеоми су локализовани на спољним ламинама костију лобање. Овакав положај ових бенигних тумора указује да су ове особе живеле без икаквих симптома, болова или било којих других тегоба проузрокованих остеомима. Поред тога, сасвим је сигурно да присуство ових промена није захтевало никакав медицински третман или лечење. У два случаја ради се о особама мушког пола, док је у једном случају остеом констатован на лобањи особе женског пола. Овај налаз је у потпуности у складу са клиничким студијама с обзиром на то да је заступљеност остеома једнака код особа женског и мушког пола (Baumhoer and Bras, 2013). Старост особа код којих су дијагностиковани остеоми на некрополи у Јакову такође се уклапа са подацима из клиничких студија. Наиме, процењује се да се остеоми најчешће дијагностикују код особа старосне доби од 30 до 50 година (Baumhoer and Bras, 2013).

Интересантан налаз забележили смо у случају лобање са ознаком 22, која је припадала женској особи која је у моменту смрти имала више од 50 година. Наиме, као што је већ поменуто у претходном тексту на овој лобањи, на десној паријеталној кости уочена је траума са знацима комплетног зарастања на унутрашњој табули и некомплетног зарастања спољашње табуле. Ова траума је највероватније настала као последица ударца неког тупог предмета. Особа је ову трауму преживела и она ни у ком случају није могла бити узрок смрти. Трауме настале дејством силе неког тупог предмета данас представљају веома честе повреде са којима се форензички лекари сусрећу и настају као последица различитих сценарија (Kranioti, 2015). Оне 
које су локализоване на костима главе од посебног су значаја зато што веома често имају смртни исход и као такве могу бити кључне у истраживањима околности под којима је смрт наступила (Kranioti, 2015). Ове повреде могу бити резултат једног догађаја или могу настати као последица више поновљених догађаја (Wedel and Galloway, 2014). У биоархеологији, трауме на лобањама овог типа веома често се везују за неки облик међуљудског насиља (Schulting and Wysocki, 2005; Djurić et al., 2006; Ahlström and Molnar, 2012; Fibiger et al., 2013; Janković et al., 2017; Scraffidi and Tung, 2020). Иако на основу локализације и изгледа ове трауме можемо да закључимо да је повреда настала највероватније приликом ударца тупим предметом у главу, услед недостатка остатка скелета, не можемо расправљати о евентуалном сценарију. Поред тога, будући да нам је за биоантрополошку анализу био на располагању само ограничен број лобања са овог локалитета, не можемо даље расправљати о евентуалним облицима или моделима међуљудског насиља у овој заједници.

У биоантрополошкој литератури cribra orbitalia ce описује као присуство коштаних лезија у виду већих или мањих пора (порозност различитог интензитета) на крововима орбита (Nathan and Haas, 1966; Stuart-Macadam, $1985,1992)$ и она се у најширем смислу повезује са лошим здравственим статусом и исхраном (Angel, 1966; Ponec and Resnick, 1984; Stuart-Macadam, 1985, 1989, 1992; Mittler and van Gerven, 1994; Fairgrieve and Molto, 2000). Многи истраживачи наводе да ове промене настају као последица анемије која настаје у раном детињству, а може бити проузрокована различитим факторима (Angel, 1966; Stuart-Macadam, 1985, 1989; Ortner, 2003; Djurić et al., 2008; Zarina et al., 2016). С једне стране, када је удружена са сличним, поротичним лезијама локализованим на другим деловима скелета или са неким специфичним дефектима костију, може водити до јасне дијагнозе као што је то случај са скорбутом или рахитисом (Buikstra, 2019). С друге стране, заједно са патолошким стањима као што су хипоплазија зубне глеђи или неки облици запаљења покоснице, поротичне промене које се јављају на орбитама представљају важан критеријум приликом истраживања такозваног физиолошког стреса код деце (Djuric et al., 2008; Oxenham and Cavill, 2010; Walker et al., 2009; Mays, 2012; Rothschild, 2012; Novak et al., 2009, 2016, 2018; Steyn et al., 2016). Из свега наведеног произилази да cribra orbitalia сама по себи може бити посматрана само као секвела неког патолошког стања и да се као таква може посматрати као неспецифичан знак. У случају лобања са некрополе Кормадин, СО је констатована код свих дечјих индивидуа. Код троје од ово четворо деце $\mathrm{CO}$ је била залечена те нам као таква може посведочити 
да су ова деца у неком моменту свог одрастања патила од неког патолошког стања или малнутриције. Једино је код детета чија лобања има ознаку 15(А) cribra orbitalia била активна. Из овога произилази да је ово дете патило од неког патолошког стања које је било активно у моменту његове смрти.

\section{Закључак}

У овом раду представљени су резултати биоантрополошке анализе хуманог остеолошког материјала са некрополе Кормадин у Јакову поред Београда. Биоантрополошком анализом обухваћено је укупно 14 лобања, међу којима су биле заступљене како дечје тако и одрасле индивидуе. Међу одраслим индивидуама заступљене су биле особе женског и мушког пола. Услед лоше очуваности скелетног материјала добијени резултати за сада нуде само штуру слику о биолошкој прошлости истраживане популације. У закључку би се требало осврнути на два најупечатљивија налаза. Пре свега, чињеница да је код свих дечјих индивидуа констатована cribra orbitalia говори у прилог тумачењу да услови живота и исхрана деце која су живела у оквиру ове заједнице нису били задовољавајући. Поред тога, на лобањи једне женске особе присутна је фрактура настала као последица ударца неког тупог предмета. Ова особа је повреду преживела и свакако је живела неколико година након настанка ове повреде. Овакав тип повреда, посебно на глави, у биоархеолошкој литератури се најчешће тумачи као последица неког облика међуљудског насиља. С друге стране, чињеница да је ова особа повреду преживела и живела годинама након ње може нам указати да су чланови ове заједнице можда познавали неке облике лечења оваквих повреда. У прилог овоме говори и чињеница да не постоје знаци инфекције, који би били сасвим очекивани. Треба нагласити да се чак и данас, у модерној медицини, у случајевима оваквих повреда као део медицинског третмана пацијенту преписују антибиотици како би се превенирао настанак инфекције.

\section{БИБЛИОГРАФИЈА}

Angel, J. L. 1966. Porotic hyperostosis, anemias, malarias, and marshes in the prehistoric eastern Mediterranean. Science 153: 760-763.

Ahlström, T., Molnar, P. 2012. The placement of the feathers: violence among Subboreal foragers from Gotland, central Baltic Sea, in Sticks, stones, and broken bones: Neolithic violence in a European perspective, eds. R. J. Schulting, L. Fibiger, 17-34, Oxford: Oxford University Press. 
Baumhoer, D., Bras, J. 2013. Osteoma, in WHO Classification of Tumours of Soft Tissue and Bone, fourth ed., eds. C. D. M. Fletcher, J. Bridge, P. Hogendoorn, F. Mertens, 276. Lyon: International Agency for Research on Cancer (IARC) and World Health Organization (WHO).

Brothwell, D. R. 1981. Digging up bones. New York: Cornell University Press.

Buikstra, J. E., Ubelaker, D. H. 1994. Standards for data collection from human skeletal remains. Fayetteville: Arkansas Archaeological Survey.

Buikstra, J. E. 2019. Ortner's identification of pathological conditions in human skeletal Remains. San Diego: Academic Press.

Булатовић, А., Капуран, А., Стругар, Н. 2010. Неолитски стратум на локалитету Кормадин у Јакову - сондажно ископавање 2008. године. Годишњак града Београда LX: 1-31.

Gray, H., Standring, S., Ellis, H., Berkovitz, B. K. B. 2005. Gray's anatomy: the anatomical basis of clinical practice. Edinburgh / New York: Elsevier Churchill Livingstone. Greenspan, A., Borys. D. 2016. Radiology and pathology correlation of bone tumors: a quick reference and review. Philadelphia: Wolters Kluwer.

Димитријевић, Д. 1960. Гепидска некропола „Кормадин” код Јакова. Рад војвођанских музеја 9: 19-52.

Djurić, M., Roberts, C., Rakočević, Z., Djonić, D., Lešić, A. 2006. Fractures in late medieval skeletal populations from Serbia. American Journal of Physical Anthropology 130(2): 167-178.

Djuric, M., Milovanovic, P., Janovic, A., Draskovic, M., Djukic, K., Milenkovic, P. 2008. Porotic lesions in immature skeletons from Stara Torina, Late Medieval Serbia. International Journal of Osteoarchaeology 18(5): 458-75.

Zarina, G., Sholts, S. B., Tichinin, A., Rudovica, V., Viksna, A., Engizere, A., Muižnieks, V., Bartelink, E. J, Wärmländer, S. K. T. S. 2016. Cribra orbitalia as a potential indicator of childhood stress: evidence from paleopathology, stable C, N, and O isotopes, and trace element concentrations in children from a 17 th $-18^{\text {th }}$ century cemetery in Jekabpils, Latvia. Journal of Trace Elements in Medicine and Biology 38: 131-137.

Janković, I., Balen, J., Ahern, J., Premužić, Z., Čavka, M., Potrebica, H., Novak, M. 2017. Prehistoric massacre revealed. Perimortem cranial trauma from Potočani, Croatia. Anthropologischer Anzeiger 74(2): 131-141.

Јовановић, Б. Глишић, Ј. 1960. Енеолитско насеље на Кормадину код Јакова. Сmaринар XI: 113-142.

Kranioti, E. 2015. Forensic investigation of cranial injuries due to blunt force trauma: current best practice. Research and Reports in Forensic Medical Science 2015/5: 25-37. Mays, S. 2012. The relationship between palaeopathology and clinical sciences, in $A$ companion to palaeopathology, ed. A. L. Grauer, 285-309. Chichester: John Wiley and Sons Ltd.

Meindl, R., Lovejoy, O. 1985. Ectocranial suture closure: a revised method for the determination of skeletal age at death based on the lateral-anterior sutures. American Journal of Physical Anthropology 68(1): 57-66. 
Mikić, Ž. 1978. O antropološkoj metodologiji terenske obrade skeletnih nalaza. Godišnjak Centra za balkanološka ispitivanja ANUBiH 16/14: 3-44.

Mittler, D., van Gerven, D. 1994. Developmental, diachronic, and demographic analysis of cribra orbitalia in the medieval Christian populations of Kulubnarti. American Journal of Physical Anthropology 93(3): 287-297.

McKinley, J. I. 2004. Compiling a skeletal inventory: disarticulated and co-mingled remains, in Guidelines to the standards for recording human remains, eds. M. Brickley, J. I. McKinley, 14 - 17. Reading: BABAO / Institute of Field Archaeologists.

Nathan, N., Haas, N. 1966. On the presence of cribra orbitalia in apes and monkeys. American Journal of Physical Anthropology 24(3): 351-359.

Novak. M., Šlaus, M., Pasarić, M. 2009. Subadult stress in the medieval and early modern populations of continental Croatia / Subadultni stres u srednjovjekovnim i novovjekovnim populacijama kontinentalne Hrvatske. Prilozi Instituta za arheologiju 26: 247-270.

Novak, M., Howcroft, R., Pinhasi, R. 2016. Child health in five early medieval Irish sites: a multidisciplinary approach. International Journal of Osteoarchaeology 27(3): 398-408.

Novak, M., Vyroubal, V., Krnčević, Ž., Petrinec, M., Howcroft, R., Pinhasi, R., Slaus,

M. 2018. Assessing childhood stress in early mediaeval Croatia by using multiple lines of inquiry. Anthropologischer Anzeiger 75(2): 155-167.

Ortner, D. J. 2003. Identification of pathological conditions in human skeletal remains. New York: Academic Press.

Oxenham, M. F. Cavill, I. 2010. Porotic hyperostosis and cribra orbitalia: the erythropoietic response to iron-deficiency anaemia. Anthropological Science 118(3): 199-200.

Ponec, D., Resnick, D. 1984. On the etiology and aathogenesis of porotic hyperostosis of the skull. Investigative Radiology 19(4): 313-317.

Premužić, Z., Šikanjić, P., Mašić, B. 2013. Frontal sinus osteoma in a 16th century skeleton from Zagreb, Croatia. International Journal of Paleopathology 3(1): 54-58.

Rothschild, B. 2012. Extirpolation of the mythology that porotic hyperostosis is caused by iron deficiency secondary to dietary shift to maize. Advances in Anthropology 2(3): 157-160.

Smith, B. H. 1984. Patterns of molar wear in hunter-gatherers and agriculturalists. American Journal of Physical Anthropology 63(1): 39-56.

Steyn, M., Voeller, S., Botha, D., Ross, A. H. 2016. Cribra orbitalia: prevalence in contemporary populations. Clinical Anatomy 29(7): 823-830.

Stuart-Macadam, P. 1985. Porotic hyperostosis: representative of a childhood condition. American Journal of Physical Anthropology 66(4): 391-398.

Stuart-Macadam, P. 1989. Porotic hyperostosis: relationship between orbital and vault lesions. American Journal of Physical Anthropology 80: 187-193.

Stuart-Macadam, P. 1992. Porotic hyperostosis: a new perspective. American Journal of Physical Anthropology 87/1992: 39-47.

Scraffidi, B., Tung, T. 2020. Endemic violence in a pre-Hispanic Andean community: a bioarchaeological study of cranial trauma from the Majes Valley, Peru. American Journal of Physical Anthropology 172(2): 246-269. 
Schulting, M., Wysocki, R. 2005. In this chambered tumulus were found cleft skulls...': an assessment of the evidence for cranial trauma in the British Neolithic. Proceedings of the Prehistoric Society 71: 107-138.

Fairgrieve, S., Molto, J. 2000. Cribra orbitalia in two temporally disjunct population samples from the Dakhleh Oasis, Egypt. American Journal of Physical Anthropology 111(3): 319-331.

Fibiger, L., Ahlstrom, T., Bennike, P., Schulting, R. 2013. Patterns of violence-related skull trauma in neolithic southern Scandinavia. American Journal of Physical Anthropology 150(2): 190-202.

Ubelaker, D. H. 1984. Estimating age at death from immature human skeletons: an overview. Journal of Forensic Science 32(5):1254-1263.

Czerniak, B. 2016. Dorfman and Czerniak's Bone Tumors, second ed. Philadelphia: Elsevier.

Šeper, M. 1952. Neolitičko naselje na Kormadinu. Arheološki vestnik 3/1: 25.

Walker, P. L., Bathurst, R. R., Richman, R., Gjerdrum, T., Andrushko. V. A. 2009. The causes of porotic hyperostosis and cribra orbitalia: a reappraisal of the iron-deficiencyanemia hypothesis. American Journal of Physical Anthropology 139(2): 109-125.

Wedel, V. L., Galloway, A. 2014. Broken bones: Anthropological analysis of blunt force trauma, second ed. Springfield: C. C. Thomas. 


\section{Ksenija Đukić, Veda Nikolić}

Laboratory for Anthropology, Faculty of Medicine, University of Belgrade

Mario Carić, Mario Novak

Laboratory for Evolutionary Anthropology and Bioarchaeology, Centre for

Applied Bioanthropology, Institute for Anthropological Research, Zagreb

\section{PRELIMINARY RESULTS OF A BIOANTHROPOLOGICAL ANALYSIS OF HUMAN SKELETAL REMAINS FROM THE CEMETERY OF KORMADIN NEAR JAKOVO}

Keywords: Kormadin, Jakovo, cribra orbitalia, impression fracture, osteoma

The aim of this study is to present the preliminary results of the bioanthropological analysis of 14 skulls from the archaeological site of Kormadin near Jakovo.

The archaeological site of Kormadin is located in Serbia, on the outskirts of Belgrade, within the municipality of Surčin and the cadastral municipality of Jakovo. This archaeological site has been excavated on several occasions since 1902, with the last archaeological campaign being conducted in 2008. Archaeological excavations revealed a vast Neolithic stratum, containing horizons with remains of residential structures, as well as a necropolis from the period of the $5^{\text {th }}-6^{\text {th }}$ century $\mathrm{AD}$. In this paper, we will present results of the bioanthropological analysis of skeletal remains from the aforementioned necropolis. Unfortunately, to date, only 14 skulls have been made available for analysis. Additionally, one complete skeleton was discovered in the campaign of 2008. However, that skeleton has not been included in the present study.

Since the first few excavation campaigns took place under the auspices of the Archaeological Museum in Zagreb, and the last few under the auspices of today's Belgrade City Museum, archaeological and bioanthropological material is now stored partly in Zagreb and partly in Belgrade and Novi Sad.

Although this site has been the subject of interest and expert research on several occasions, and a total of 56 graves and two isolated buried skulls have been found, the human osteological material has not been bioanthropologically analysed, and nothing is known about the biological past of the people who were buried in this necropolis.

The bioanthropological analysis was carried out at the Laboratory for Evolutionary Anthropology and Bioarchaeology, Institute for Anthropological Research, in Zagreb, and at the Laboratory for Anthropology, Faculty of Medi- 
cine, in Belgrade. A total of 14 skulls were investigated. During the bioanthropological analysis, standard bioanthropological procedures were followed. Out of the 14 skulls, six were male and three were female, while it was not possible to establish the sex for one of them. Among the skulls, there was a total of 10 adults and four children.

During the bioanthropological analysis, cribra orbitalia was noted in all nonadult individuals, the presence of osteoma in three adult individuals, and one blunt force trauma of the skull was noted in one adult female. In addition, one of the most significant finds from this necropolis, in terms of the human osteological material, was certainly an artificially deformed skull. This skull belonged to a female who was over 50 years old at the time of death.

Due to the scarcity and poor preservation of the skeletal material, the results obtained so far offer only a vague picture of the biological past of the studied population.

In conclusion, two particularly striking observations should be highlighted. First of all, the fact that cribra orbitalia was found in all children strongly suggests that the living conditions and nutrition of children who lived within this community were not satisfactory. In addition, a fracture was found on the skull of a woman, which was caused by the impact of a blunt object. This person survived the injury and certainly lived for several years after it occurred. This type of injury, especially on the head, is most often interpreted in bioarchaeological literature as a consequence of some form of interpersonal violence. Given that this person survived the injury and lived for years afterwards may indicate that members of this community had knowledge of some forms of treatment for such injuries. The fact that there are no signs of any expected infection would appear to support this supposition. It should be emphasised that even today, in modern medicine, in cases of such injuries, more often than not, antibiotics are prescribed to the patient as part of the treatment, in order to prevent the occurrence of infection. 